\title{
KINERJA LEMBAGA KEUANGAN BANK SYARIAH DI INDONESIA
}

\author{
Dian Indah Cahyani \\ Sekolah Tinggi Ilmu Ekonomi AAS Surakarta \\ Email:dian.indahc@gmail.com
}

\begin{abstract}
The purpose of this study is to see the performance of financial institutions, especially sharia banking in Indonesia in the period 1998 to mid 2015 in terms of market share when compared with conventional banking. The research method using the literacy method by looking at the data that support the research problems undertaken. The results show that for 14 years from 1998 to 2012, the level of development of Islamic banks in Indonesia is very remarkable, with an average growth of around 45\% -78\% per year, but in 2013 to mid 2015 results was found not as expected, where the market share of sharia banks is only $4.85 \%$ compared to conventional banks.
\end{abstract}

Keywords: performance, financial institution, sharia bank

\section{PENDAHULUAN}

Setiap usaha yang dilakukan oleh suatu lembaga tentunya harus memiliki suatu ukuran kinerja. Kinerja akan dapat menghasilkan sesuatu yang dinginkan bahka dapat melebihi harapan jika semua elemen yang dapa pada perusahaan atau lembaga tersebut mampu berkerja secara bersama-sama serta masing individu yang ada di dalamnya mau mencurankan semua kemampuannya dalam bentuk kinerja yang baik. Salah satu ukuran kinerja adalah luasnya pangsa pasar yang dikuasai oleh perusahaan atau lembaga dibandingkan dengan perusahaan atau lembaga yang sejenis lainnya. Salah satu lembaga yang sedang dalam perbincangan hangat adalah lembaga keuangan perbankan syariah dengan lembaga keuangan perbankan konvensional. Kemudian jika kita melihat perkembangan lembaga keuangan saat ini, sedang ramai diperbincangkan tentang pesatnya perkembangan lembaga keuangan berbasis syariah, sampai-sampai banyak lembaga keuangan konvensional membuka unit-unit syariah (Wardani \& Tho'in, 2013).

Pangsa pasar yang semakin meningkat menjadi indikasi adanya suatu kinerja yang semakin baik yang ada diperusahaan tersebut, termasuk pula dalam hal ini mampu memberikan harapan-harapan nasabah perbankan yang ada. Namun sebaliknya, jika pangsa pasarnya tetap atau bahkan menurun menunjukkan adanya kinerja yang stangnan atau kinerja yang semakin menurun pula, baik secara individu maupun secara kolektif, termasuk hadirnya lembaga ini belum mampu secara maksimal dalam memenuhi harapanharapan nasabah perbankan, terlebih dalam hal pelayanan seperti pelayanan yang diberikan oleh bank konvensional. Sebagaimana menurut Tho'in (2011), bahwa kualitas pelayanan berpusat pada upaya pemenuhan 
kebutuhan dan keinginan pelanggan serta ketepatan penyampaiannya untuk mengimbangi harapan pelanggan. Bank syariah sebagai lembaga keuangan yang dalam usahanya menggunakan prinsip-prinsip syariah harus segera melihat adanya ketatnya persaingan ini dengan terus melakukan peningkatan kinerja agar pangsa pasar yang dimilikinya juga semakin berkembang dan juga semakin luas. Dengan perkembangan waktu yang ada apakan eksistensi lembaga keuangan perbankan syariah ini mampu bertahan dan bahkan mampu meningkatkan pangsa pasarnya, tentunya semua itu akan dapat dilihat dari berjalannya dari waktu ke waktu.

Oleh karena itu penelitian ini akan mencoba melihat kinerja yang dilakukan lembaga keuangan, khususnya perbankan syariah di Indonesia dalam kurun waktu tahun 1998 sampai dengan pertengahan tahun 2015 ditinjau dari pangsa pasarnya bila dibandingkan dengan perbankan konvensional.

\section{TUJUAN PENELITIAN}

Tujuan Penelitian ini adalah ingin melihat kinerja yang dilakukan lembaga keuangan, khususnya perbankan syariah di Indonesia dalam kurun waktu tahun 1998 sampai dengan pertengahan tahun 2015 ditinjau dari pangsa pasarnya bila dibandingkan dengan perbankan konvensional.

\section{KAJIAN PUSTAKA}

\section{Kinerja}

Kinerja merupakan hasil kerja dinilai secara kualitas dan kuantitas yang dapat dicapai pegawai dalam menjalankan tugas yang diemban sesuai dengan tanggung jawab yang diberikan kepadanya (Mangkunegara, 2000: 67). Pendapat tersebut didukung Hasibuan (2001:34). Sulistiyani menambahkan, hasil kerja yang dinilai melalui kombinasi dari kemampuan, usaha, serta kesempatan atau peluang merupakan kinerja.

Menurut Mink (1993) yang diterangkan pula oleh Nuryanto \& Tho'in (2014) Kinerja merupakan suatu kondisi yang harus diketahui serta dikonfirmasikan untuk para pihak yang bersangkutan, untuk melihat tingkat pencapaian hasil suatu instansi dihubungkan dengan visi serta mengetahui dampak positif dan negatif dari suatu kebijakan-kebijakan operasionalnya. Individu yang memiliki kinerja yang tinggi memiliki beberapa karakteristik khusus. Diantara karakteristik tersebut: (a) individu yang selalu berorientasi prestasi, (b) memiliki percaya diri, (c) berperngendalian diri, (d) kompetensi.

Dalam penilaian kinerja tentunya memiliki berbagai manfaat yang dapat membantu perusahaan. Manfaat dari penilaian kinerja perusahaan antara lain:

1. Untuk mengukur prestasi yang dicapai oleh suatu organisasi dalam suatu periode tertentu yang dapat mencerminkan berbagai 
tingkat keberhasilan dalam melaksanakan aktifitasnya.

2. Untuk melihat kinerja organisasi secara keseluruhan, pengukuran dalam prestasi atau kinerja dalam menilai suatu kontribusi per bagian dalam pencapaian tujuan perusahaan secara keseluruhan.

3. Dapat digunakan sebagai dasar penentuan strategi perusahaan untuk masa yang akan datang.

4. Memberi berbagai petunjuk untuk pembuatan berbagai keputusan dalam kegiatan yang dilakukan perusahaan pada umumnya, dan divisi atau bagian organisasi pada khususnya.

5. Untuk fondasi di dalam menentukanan berbagai kebijakan penanaman investasi agar dapat meningkatkan efisiensi dan produktivitas perusahaan.

\section{Lembaga Keuangan}

Keputusan SK Menkeu RI no.792 tahun 1990: Bahwa lembaga keuangan ialah seluruh badan usaha yang bergerak dibidang keuangan dimana hal yang dilakukan adalah menghimpun dana dan menyalurkannya kepada masyarakat atau nasabah terutama untuk biaya investasi pembangunan.

Pasal 1 UU no.14 tahun 1967 yang telah terganti dengan UU no.7 tahun 1992: Menyatakan bahwa perbankan di negara Indonesia yaitu lembaga keuangan merupakan suatu badan yang kegiatannya menarik hasil- hasil dana dari nasabah atau masyarakat yang kemudian disalurkan kembali pada masyarakat.

Menurut Dahlan Siamat lembaga keuangan ialah badan usaha yang kekayaannya itu dalam bentuk aset keuangan dibanding aset non-finansial atau riil. Dimana lembaga keuangan sudah memberikan kredit atau pembiayaan terhadap nasabah dan menanamkan dananya pada surat yang berharga (Susanto, 2015).

\section{Bank Syariah}

Bank Syariah adalah bagian dari Perbankan Syariah selain dari Unit Usaha Syariah (UUS), sedangkan Bank Syariah terdiri atas Bank Umum Syariah dan Bank Pembiayaan Rakyat Syariah (BPRS). Dalam Undang-Undang perbankan Indonesia (Undang-undang Nomor 10 Tahun 1998) membedakan bank berdasarkan kegiatan usahanya menjadi dua, yaitu bank yang melaksanakan kegiatan usaha secara konvensional dan bank yang melaksanakan kegiatan usaha berdasarkan prinsip syariah. Prinsip Syariah, adalah prinsip Hukum Islam dalam kegiatan perbankan berdasarkan fatwa yang dikeluarkan oleh lembaga yang memiliki kewenangan dalam penetapan fatwa dibidang perbankan syariah (Pasal 1 Angka 12 UndangUndang Nomor 21 Tahun 2008 tentang Perbankan Syariah). 
Menurut Pasal 2 Undang-Undang Nomor 21 Tahun 2008 dinyatakan bahwa kegiatan bank syariah harus berasaskan prinsip syariah, demokrasi ekonomi, dan prinsip kehati-hatian. Dalam Penjelasan Pasal 2 tersebut dikemukakan kegiatan usaha yang berasaskan prinsip syariah, antara lain adalah kegiatan usaha yang tidak mengandung unsur:

1. riba, yaitu penambahan pendapatan secara tidak sah (batil) antara lain dalam transaksi pertukaran barang sejenis yang tidak sama kualitas, kuantitas, dan waktu penyerahan (fadhl), atau dalam transaksi pinjammeminjam yang mempersyaratkan Nasabah Penerima Fasilitas mengembalikan dana yang diterima melebihi pokok pinjaman karena berjalannya waktu (nasi'ah).

2. maisir, yaitu transaksi yang digantungkan pada suatu keadaan yang tidak pasti dan bersifat untung-untungan.

3. gharar, yitu transaksi yang objeknya tidak jelas, tidak dimiliki, tidak diketahui keberadaannya, atau tidak dapat diserahkan pada saat transaksi dilakukan kecuali diatur lain dalam syariah.

4. haram, yaitu transaksi yang objeknya dilarang dalam syariah, atau

5. zalim, yaitu transaksi yang menimbulkan ketidakadilan bagi pihak lainya.

\section{METODE PENELITIAN}

Metode penelitian dengan menggunakan metode literasi dengan melihat data-data yang mendukung permasalahan penelitian yang dilakukan.

\section{PEMBAHASAN}

Dalam Bank Indonesia outlook data data dapat diketahui bahwa terhitung mulai dari tahun 1998 sampai dengan tahun 2012, tingkat pertumbuhan atau perkembangan bank syariah di Indonesia hasil yang telah dicapai sangat memuaskan bagi para penggiat perbankan syariah, dimana pertumbuhan yang telah dicapai selama 14 tahun tersebut rata-rata 45\%-78\% per tahun. Tetapi ketika memasuki tahun 2013 yang tentunya dari perbankan syariah membuat target-target pertumbuhan yang lebih tinggi untuk tahun-tahun berikutnya bahkan di tahun 2015 membuat target capaian pangsa pasar sampai dengan $15 \%$ bila dibandingkan dengan bank konvensional.

Hal di atas, bertolak belakang dengan pertumbuhan bank syariah akhir-akhir ini yang telah ditentukan targetnya. Jika melihat dan mencermati dan mempelajari data-data yang ada dalam kurun waktu tahun 2013 sampai tahun 2015 atau yang sering disebut fase ke empat pertumbuhan bank syariah, di mana antara perkembangan atau jumlah jaringan usaha syariah serta kantor perbankan dengan perkembangan aset menunjukkan hasil yang 
tidak sesuai dengan target dan harapan yang diinginkan. Dalam statistik perbankan Indonesia per Desember 2014 terdapat tidak kurang 22 Unit Usaha Syariah (UUS) dari suatu bank konvensional dan 12 Bank Umum Syariah (BUS) dengan total keseluruhan jaringan kantor 2.151 unit yang ada. Selain itu, total aset Bank Umum Syariah yang ada di Indonesia telah mencapai jumlah 272.343 miliar rupiah. Dari jumlah yang tertera tersebut masih sangat kecil dan masih kalah jauh jika dibandingkan dengan total aset dari perbankan nasional yang mayoritas dikuasai oleh bank konvensional yang telah beroperasi lebih lama, yang secara umum telah mencapai angka 5.615.150 miliar rupiah (Bank Indonesia, 2014). Dari data-data yang ada di atas menunjukkan bahwasanya jumlah atas penguasaan pasar atau pangsa pasar perbankan syariah di Indonesia yang ada sampai saat ini masih sangat kecil sekali di tengah-tengah masyarkat Indonesia yang mayoritas muslim, yaitu hanya berada pada tingkat prosentase $4,85 \%$, sangat jauh bila dibandingkan dengan pangsa pasar yang telah dimiliki dan dikuasai oleh bank konvensional yang telah mencapai pada angka prosestase $95,15 \%$ dari seluruh total pangsa pasar perbankkan yang ada di Indonesia. Dengan demikian, target pangsa pasar yang telah ditentukan, ditargetkan, dan ingin dicapai oleh perbankan syariah sebesar 15\% pada akhir tahun 2015 masih sangat jauh sekali dari harapan. Data-data tersebut adalah data yang riil dan tidak dapat ditampik. Oleh sebab itu tentunya harus menjadi motivasi dan dorongan bagi kita semua para penggiat ekonomi Islam, khususnya dalam hal ini adalah para praktisi yang terlibat langsung dengan perbankan syariah, agar segera mengambil tindakan serta mencari berbagai strategi di dalam pengembangan, tentunya strategi yang mampu menjadikan bank syariah agar memiliki kinerja lebih maksimal guna mempertahankan dan memperluas pangsa pasar secara nasional, baik dari sisi kinerja pelayanan, kinerja dalam menginovasi produk maupun kinerja-kinerja yang lain yang dinilai mampu mengangkat citra dan kepercayaan masyarakat terhadap bank syariah, sehingga pangsa pasar yang diharapkan dapat tercapai.

\section{KESIMPULAN}

Dari uraian-uraian yang ada di atas, maka dapat diambil kesimpulan, bahwa kinerja lembaga keuangan bank syariah selama 14 tahun lamanya, terhitung sejak tahun 1998 sampai tahun 2012, tingkat perkembangan bank syariah di Indonesia sangat luar biasa meningkat dengan sangat pesat, dengan rata-rata pertumbuhan yaitu berkisar 45\%-78\% per tahun, tetapi sebaliknya pada tahun 2013 sampai pertengahan tahun 2015 hasil yang didapatkan tidak sesuai yang diharapkan dan dicita-citakan, dimana pangsa pasar bank syariah hanya $4,85 \%$ dibandingkan bank konvensional yang menjapai 95,15\%. 


\section{DAFTAR PUSTAKA}

Bank Indonesia

Hasibuan. (2001). Akuntansi Manajemen.

Yogyakarta : Balai Pustaka.

Keputusan SK Menkeu RI no.792 tahun 1990

Mangkunegara, Anwar Prabu. (2000). Manajemen Sumber Daya Manusia Perusahaan. Bandung: PT. Remaja Rosdakarya.

Mink. (1993). Karakteristik Kinerja Individu. Jakarta: Balai Pustaka.

Nuryanto, R., Tho'in, M., \& Wardani, H. K. (2014). Rasio Likuiditas, Rasio Solvabilitas, Rasio Rentabilitas Koperasi Jasa Keuangan Syariah Di Jawa Tengah. Jurnal Akuntansi dan Pajak, 15(01).

Pasal 1 UU no.14 tahun 1967

Pasal 1 Angka 12 Undang-Undang Nomor 21 Tahun 2008 tentang Perbankan Syariah. statistik perbankan Indonesia per Desember 2014.

Susanto, Bob. (2015). Pengertian Lembaga Keuangan Menurut Para Ahli. http://www.spengetahuan.com/2015/03/ pengertian-lembaga-keuangan-menurutpara-ahli.html. Diakses 11 April 2015.

Tho'in, M. (2011). Pengaruh Faktor-faktor Kualitas Jasa terhadap Kepuasan Nasabah di Baitul Mal Wat Tamwil (BMT) Tekun Karanggede Boyolali. MUQTASID Jurnal Ekonomi dan Perbankan Syariah, 2(1), 73-89.

Undang-undang Nomor 10 Tahun 1998

Wardani, H. K., \& Tho'in, M. (2013). Pengelolaan Baitul Maal Dalam Meningkatkan Kesejahteraan Negara. Jurnal Akuntansi dan Pajak, 14(01). 